\title{
A Century of Mass Media and Nigeria's Development: Issues and Challenges
}

\author{
Ifedayo Daramola, $\mathrm{PhD}$ \\ Head of Department of Mass Communication \\ Adekunle Ajasin University, Akungba-Akoko, \\ Ondo State, Nigeria
}

\begin{abstract}
In 2014, Nigeria became 100 years as an entity following the amalgamation of the Northern and Southern protectorates by Sir Lord Lugard, the British colonial Governor-General in 1914. This paper therefore examines the role played by the Nigerian media particularly newspaper press in the decolonization of the country from 1881 to 1960 . The first newspaper in Nigeria published by Reverend Henry Townsend (Iwe Irohin) was debut in Abeokuta in 1859. But as from 1881, the Lagos Times and Gold Coast Advertiser published by Richard Beale Blaize began to champion the cause for representative government. This noble cause attracted subsequent newspapers such as Weekly Record of the Jacksons, Nigeria Times of James Bright Davies, Lagos Daily News of Herbert Macaulay, West African Pilot of Nnamdi Azikiwe, Nigerian Tribune of Obafemi Awolowo among others. All the newspapers opposed British colonial administration and agitated for independence. Apart from their pungent writings which were critical of the colonial government, many of the proprietors led protest to England to demand for independence. The agitations finally led to independence on October 1, 1960. While applauding the media for its effort so far, this paper however, laments the low performance of the media in the 2015 General elections when the media descended so low by taking position on the side of the ruling political party which turned out to favour an opposition party.
\end{abstract}

\section{Keywords}

Nigeria, Amalgamation, Lord Lugard, Decolonization, Newspaper Press, Independence, Better Society

\section{INTRODUCTION}

\section{Mass media: Its Origin in Africa}

The Nigerian press predates Nigeria as an entity. The newspaper press began in 1859 , fifty years before the country, Nigeria came into existence through the amalgamation of northern and southern protectorates in 1914. The mass media came to Africa via the missionaries to propagate Christianity. Initially, the Christian missionaries introduced reading and writing culture. Thus the press was introduced to propagate Christianity and later to educate the Africans to also afford the colonial masters the opportunity to communicate with large number of people simultaneously in their own language which could be English, Portuguese, Durtch, German, French and Spanish depending on the region. Little wonder then that the early print media were created to serve the colonialists and not the native population.

To guide our discussion on the structure and events of the
Nigerian print media, it is apposite to fashion the discussion along four notable periods in the political history of Nigeria, both as a nation and as a colony, in relation to the practice of journalism. The four notable periods in Nigerian press are: Missionary era; colonial era (before and after independence) civilian era (comprising first, second, third and the current republics) and military era, which covers the regimes of Yakubu Gowon; Murtala/Obasanjo; Buhari /Idiagbon; Ibrahim Babangida; Sani Abacha and Abdulsalam Abubakar.

Before that decade, the British colonialist depended on the print media for publicity and propaganda but in 1932, they added radio to their arsenal of information dissemination. By that year it had been assuming the status of a mass medium and was in fact supplementing the print medium in Europe and North America.

\section{Genesis of Nigerian Press}

\section{Iwe Irohin}

In Nigeria the first printing press was installed by the Presbyterian in Calabar when the missionaries arrived in 1846 (Omu, 1978:7). The first newspaper in Nigeria was, however, established in Abeokuta in 1859 by an Anglican Missionary, Rev. Henry Townsend. According to Omu, "eight years after the first printing press by the Presbyterian in Calabar, Reverend Henry Townsend fitted up a printing press and inaugurated a printing school in the mission compound at Abeokuta. But then in 1859, Townsend founded the Iwe Irohin (Iwe Irohin fun awon Ara Egba ati Yoruba) which appeared fortnightly as a Yoruba language newspaper but became bilingual when an English language supplement was introduced from 8th March, 1866 (Omu, 1978, Duyile, 1987).

Reverend Townsend newspaper played an active role in Egba politics and so often proclaimed the Egba's point of view. In 1867 when some Egba chiefs rose against the Europeans to protest the British policy on the annexation of Lagos which affected Abeokuta's claim over some important towns and villages near Lagos, the Iwe-Irohin got involved and could not escape the local hostility which accompanied the riots.

But it must be noted that Reverend Townsend can be described as the father of journalism in Nigeria. $\mathrm{He}$ became a recognized, influential and respected Anglican religious minister and he personally put Abeokuta's political influence and its educational image and culture above any of the Yoruba towns of the period. He was also the author of the Egba people deliverance from the people of DAHOMI (Coker, 1968). 
Henry Townsend was born in a city called Exeter in the Devon county, England. The Townsend family was famous for publishing and printing. When Townsend came to Nigeria (Badagry) in 1842 he came with his printing press from where he later moved to Abeokuta, the current capital of Ogun state (Daramola, 2013).

As earlier said, the missionaries through the mass media introduced education, the culture of reading and writing, investigating, science, technology, trade and commerce, communication, religious study which was their primary objective and health, exposing us to other cultures and languages, opportunity to be a member of the outside world, and in the final analysis propelled us to be seeking for information and being inquisitive. With the arrival of the missionaries, the various kingdoms which later became Nigeria after the amalgamation in 1914 began to participate in what was hitherto outside their sphere such as joining the West African frontier force based in the then Gold Coast (Ghana) e.g. the Burma war. Because Africans were denied effective political participation in a situation of crown colonial rule the rural press developed into an advocacy group. It followed that the Nigerian press assumed the role of the opposition and sought to rival the colonialists, encouraging political awareness and involvement by providing means of criticism of the authorities and spreading disaffection with official plans and policies. This is why such newspapers as the Lagos Times and Gold Coast Colony Advertiser of Richard Blaize (1880 - 1883), the Weekly Record of John Payne Jackson and Thomas Horatio Jackson (1891- 1930), the Lagos Standard, of George Alfred Williams, Lagos Daily News of Herbert Macaulay (1925 - 1938), West African Pilot of Dr. Nnamdi Azikiwe (1937 - 1960), and Nigerian Tribune of Chief Obafemi Awolowo (1949 to date) were critical of colonial rule and their agitation led to their being jailed or banned from circulation which was usually followed by mass protest by their followers.

Contributions of press icon to development and agitation for independence

Press agitation really began with the first newspaper in Nigeria, Iwe Irohin which criticized the British colonial government over slave trade and immigration policy. Due to his agitation for the abolition of slave trade, Townsend was intimidated by the crown and the intensity of his agitation reduced on his coming back. In no small measure, however, Townsend contributed his widow's mite to abolition of slave trade.

\section{The “Anglo African" of Robert Campbell}

The Anglo African is on record as the second newspaper in Nigeria while the then Iwe Irohin was based in Abeokuta the Anglo African was based in Lagos on the Island and was owned by Mr. Robert Campbell. The publication of the Anglo African started in 1863. Both Reverend Townsend and Robert Campbell were friends and the latter even lent helping hand to Reverend Townsend's press. They in turn were responsible for the great advancement and training of Nigeria printers.

Robert Campbell brought in a printing press in 1862 and Richard Beale Blaize a future newspaper owner, established the Caxton printing press in 1875 . It must be said that Campbell did not establish the Anglo African based on ideology or principle but was just exploiting the growing interest in western education and enlightenment in Lagos in the 1800 s by providing cheap and accessible material which would educate and entertain readers. As a professional printer and teacher it was easy for Campbell to become a publisher.

The Anglo African was heavily involved in the politics of Lagos. Campbell was in the fore-front in the agitation for the separation of Lagos from the Gold Coast Administration. Thus, Robert Campbell, devoted his time to promoting the interest and welfare of Lagos. His journalism can be described as literary journalism which was meant to exploit the growing interest in education which started in 1859 with the establishment of CMS Grammar School by the CMS mission. In 1873, the female institution for Anglican Girls was established. Three years later, the Methodist Boys' High School was founded, shortly followed by the Methodist Girls' High School (Omu: 1978: 22). His contribution was basically of promoting and entrenching education. He established 'Lagos Academy' where he gave lectures on human physiology. "His literary achievements" according to Omu (1978:20) "were to earn him the title of "Professor".

\section{Lagos Times}

The publisher of Lagos Times and Gold Coast Colony Advertiser (1880 - 1883), the third newspaper Richard Beale Blaize was a non-conformist and a professional printer. He used his paper to publish burning issues of his time. His paper had more qualities than the newspapers that existed before his and it was the first rural newspaper to have sales depot outside the shore of Nigeria and as far as London. He was internationally recognized. His paper started agitation for equal rights and inclusive government. In its issue of October 2, 1881, the newspaper lamented, "no council and no house of assembly exist in which the people serve as elected representatives. The government is personal and the council, which sits in Accra, is not representative of the wishes of the people" (Omu, 1978).

In a nutshell, Lagos Times was a radical newspaper which set the ball rolling for agitation for decolonization and eventual independence. As a matter of fact, in its editorial of March 9, 1881, the paper said, "we are not clamouring for immediate independence but it should always be borne in mind that the present order of things will not last forever". The paper warned, "a time will come when the colonies on the West Coast will be left to regulate their own internal and external affairs" (Coker, 1968:9). This prophecy was fulfilled on October 1, 1960 when Nigeria became independent of the crown.

\section{Lagos Observer}

The fourth newspaper, Lagos Observer established by J. Began Benjamin, a member of Lagos Chamber of Commerce had moral and financial support of Dr. N. T. King and Robert Campbell who were at various times members of the editorial committee of the newspaper (Omu, 1978). The newspaper was a progressive, radical, anti-imperialist, cultural and religious newspaper. Its agitation for cultural nationalism and religious independence led to the establishment of first African church in Nigeria which is the native Baptist church. The paper also involved itself in the administration of justice in Nigeria. In its issue of May 18, 1882, J. B. Benjamin wrote an article on the administration of Justice in Nigeria 
in which he alleged that judges were involved in anti-negro prejudice for this he was charged with criminal libel and convicted. In conclusion, the Lagos Observer was outspoken, pungent and oozed out radicalism in content and outlook (Daramola, 2013:22).

\section{Lagos Weekly Record}

John Payne Jackson was the publisher of Lagos Weekly Record. The newspaper was highly political. John Payne Jackson had an unequalled record in pungency, consistency in editorial content and regularity in appearance from $1891-1930$. The publication played a vital role in the early resistance movement which kept colonialism constantly in check during and after the Lugard's administration in Nigeria.

Lord Lugard was very hostile to John Payne Jackson and other newspaper publishers of that time. The press as an institution played a massive public communication role too important to be forgotten in the account and analysis of the growth of Nigerian press with men like John Payne Jackson and later his son Thomas Horatio Jackson. And from that period Nigerian journalism began to have a new recognition through the might of Jackson's pen. He was vehemently against the European apartheid policies, a nationalist to the core, principled and was credited with the efforts in bringing a positive force into Nigerian Journalism through his harshly worded writings. He even went on to call Lord Lugard a "Negrophobist", an untrammeled despot and an 'OGRE'.

John Payne Jackson's politics extended beyond Nigeria. He personally led many protest group in search of political justice for Africans. He took swipes at the northern establishment. He never saw himself as an English man and in comparism with contemporaries, the Weekly Record newspaper was radical in content and outlook.

The appearance of the Weekly Record of John Payne Jackson in 1891 marked a turning point in the history of the press in Nigeria. Jackson was everything in one. Firstly, he believed strongly in the dignity of the black race. He was a nationalist, traditionalist, mentor, fighter, and advocate who used his newspaper to influence the reaction of the people against the colonialists. He could also be described as a radical who was ready to lead protest and agitation. The newspaper became influential for its editorial candidness, toughness and critical appraisal of colonial administration. He was the most outstanding journalist in West Africa during his period. John Payne Jackson read widely and could speak on any subject. His journalism was a crusade journalism. He was scholarly, marked by quotations and references. He spoke almost on all issues. His paper was a training ground for many future journalists.

After his death in 1915, his son Thomas Horatio Jackson took over the paper. He was a determined agent in the propagation of racial consciousness. Judged by the intensity of assault of the colonial administration, its pungent criticism expressed in lengthy editorial always hanged on the edge of sedition. Kalu Ezera described the paper as the first militantly nationalist newspaper. He was also described as father of African nationalism.

In conclusion, the contribution of Thomas Horatio Jackson to the emancipation of the Black race cannot be swept under the carpet. He was a dogged fighter for equal right, freedom, and self-determination. He agitated for African type of education in which the Africans will not be westernized. Both Jacksons were good managers of human and material resources in that they were successful and discipline in the management of the newspaper which lasted longer than any of its contemporaries. Horatio Jackson was known to have coined and used the word, imperialism in his newspaper. The confrontational stance of the paper was to earn Horatio Jackson, imprisonment from the colonialists after the death of his father. He was jailed for his article entitled, "There is no justice in Nigeria". He was convicted for seditious libel and contempt of court (Coker, 1968).

\section{The press and Amalgamation}

The agitation for amalgamation by the British government under Lord Frederick Lugard was very unpopular with the educated southern Nigerians made up of educated elites and young journalists who had just come to the scene then. The Record and some other newspapers were the mouth piece of the educated elites. In one editorial concerning amalgamation by Record Horatio Jackson wrote, "To attempt to set back the hands of the clock of progress by foisting upon the more favoured south, the despotic rule of the northern provinces, thereby giving them a sense of militarism which can only create the spirit of disaffection among a liberty loving people whose loyalty is proverbial and utilizing that every spirit of disaffection is a means of their further humiliation..." (Omu, 1978). In spite of opposition to amalgamation, Lord Lugard went ahead and the result is what we are seeing today- tribal politics, tribal sentiment, religious intolerance, unequal development, difference in education, between south and the north, employment policy based on federal character and not on merit, political imbalance. However, the amalgamation has also been of benefit in sharing our resources amongst each ethnic group. It is indisputable that the North provides bulk of the food we eat today, South West provide intellectual and economic tonic while the South East is the technological engine room for the country.

\section{Nigerian Chronicle}

On November 20, 1908, Christopher Kumolu Johnson and Emmanuel T. Johnson established a paper which was called Nigerian Chronicle. The chronicle was a revolution in the sense that it was the first true Nigerian newspaper that carried 'Nigerian' in its masthead in anticipation of the amalgamation of the southern and northern protectorates. As far back as 1900, the area around Niger had been named 'Nigeria' by Miss. Flora Shaw, a journalist who later got married to Lord Lugard. Nigerian Chronicle was popular for its editorial candidness and the paper wore the appearance of a national newspaper. The Chronicle was born in an era of stringent media law, that is the 1903 newspaper Ordinance which "set out who may or may not operate a newspaper and also what a newspaper may look like and was followed by the Seditious Offences Ordinance of 1909" (Duyile, 1989:88) and later incorporated into the criminal code of 1916 (Coker, 1968:12). This goes to say the paper passed through the legal test of the British government for it to be allowed to come into existence. The Media Law and the criminal code were reactions to the constant attacks and critical comments regarding the effort to merge the northern 
protectorates with southern protectorates and Lagos colony.

\section{African Messenger}

Ernest Ikoli started his newspaper, African Messenger on March 10, 1921. He was both its publisher and editor. The "Messenger" was a weekly paper (Daramola:50). He was a member of Nigerian Youth Movement (NYM) and was very active in politics. With the likes of Ernest Ikoli who was very active in politics in the early part of the local press the foundation for the entrenchment of Democracy in Nigeria was laid. When party politics began in the 1920s he used The Messenger to inspire the formation of the "Union of Young Nigerians"

Most pioneering journalists were well educated. Their newspapers had many local content. Although, most of the early journalist were nationalistic in approach in their writings but they in turn were well informed, which is an important aspect of education. But after independence in 1960 their focus was on education and other pressing national issues. The paper was a moderate which acted as a third force between the then existing newspapers. When party politics began in the 1920s, he used the Messenger to inspire the formation of the "Union of Young Nigerians', a party that steered a middle course between the Herbert Macaulay-led Nigeria National Democratic Party, NNDP and the Reform club led by Sir Kitoyi Ajasa of Nigerian Pioneer. He later sold the paper to publishers of Daily Times and became the first editor of the paper (Daily Times) in 1926 which was established as the mouth organ of the colonial government (Coker, 1968, Omu, 1978, Duyile, 1989, Daramola, 2013).

\section{Nigerian Times}

During the same time, another newspaper carrying 'Nigerian' in its masthead was the Nigerian Times which was jointly established by Barrister Sapara Williams (father of Chief Rotimi Williams) and James Bright Davies, a distinguished civil servant in Sierra Leone who had his job terminated for his clandestine antigovernment journalism. In the maiden issue of the paper, Davies declared that he was determined to express opinion and pass judgment, measures freely and frankly and with open candor and he stood by this declaration. Though the declaration earned him a jail term and fines on November 6, 1916 when he was convicted for seditious writing and sent to jail for six months to the great delight of Lord Lugard (Daramola, 2013, Omu, 1978). The paper was influential and was well patronized. As a matter of fact many admirers of the paper made unsolicited donations to it each time it had financial problem. In 1914, following the amalgamation of the Northern and Southern protectorates of Nigeria Davies renamed the newspaper, Times of Nigeria. Davies died on January 12, 1920 a hero.

\section{Nigerian Pioneer}

Another newspaper of the period was the Nigerian Pioneer set up by a lawyer, Sir Kitoyi Ajasa. He was very close to the establishment. As a matter of fact, he was a personal friend of Lord Lugard. Unlike the newspapers before it the Nigerian Pionner was conservative because it was established to give support to the colonial government and this support earned the proprietor many appointment and influence in the colonial government. Kitoyi Ajasa was more or less a stooge to the British government. His paper had little or no impact on the society.

\section{Lagos Daily News}

Another icon and publisher of the "Lagos Daily News" Herbert Macaulay who was the grand son of Bishop Ajayi Crowther. Herbert Macaulay was rose through the foundation of education and he imparted this in his newspaper, the Lagos Daily News he was also a graduate of Civil Engineering.

Herbert Macaulay bought the newspaper from the original owner Mr. Victor Bababoni. Macaulay was first a politician, publisher, writer, activist, nationalist and surveyor. In partnerships with Horatio Jackson of the Weekly Record, he was also the founder of the first officially recognized political party in Nigeria, Nigeria National Democratic Party (NNDP). He used the paper to champion the cause of his party. $\mathrm{He}$ was popularly referred to as the Gandhi of West Africa, the defender of native right. Once he has written an article, no matter the extent of libel, nothing could prevent him from publishing it. He was called father of Nigerian nationalism (Duyile, 1989, Omu, 1978, Coker, 1968, Daramola, 2013).

Herbert Macaulay was a grassroots man, he was very close to the people although he was from a rich background. This helped him in his political adventure. Due to the agitation of the pressmen an other nationalists for self determination and representative government, in 1922 a constitution embodying elective principle was adopted by the governor of Nigeria, Sir Hugh Clifford.

This style earned him more enemies than friends particularly from his African counterparts such as Barrister Kitoyi Ajasa, Dr. Henry Carr, Dr. Obasa and Dr. Randle who were seriously lashed and lambasted by his paper. On July 6, 1928, Herbert Macaulay was convicted for publishing rumours with intent to incite one class of the community against another. $\mathrm{He}$ was found guilty and sentenced to imprisonment for six months without an option of fine (Omu, 1978). Macaulay's imprisonment by the crown was as a result of his criticism of the policies and actions of the colonialists. And also, he was against anyone who had sympathy for the colonial government. This is why the editor of the Lagos Daily News, Dr. Olusola Caulcrick who was brought to trial along Macaulay was given an option of fine ( $£ 50)$ but Macaulay was not so lucky he was sent to jail. Macaulay was made the president of NCNC in his old age, he died in May 7 , 1946.

\section{Daily Times}

Daily Times was set up in 1926 by some European merchants in partnership with a Nigerian, Sir Adeyemo Alakija. Though a conservative newspaper, Daily Times went through three major changes or take overs in its history. It experienced the first take over in 1935 when it suffered a decline in circulation and advertisement revenue due to the world wide economic depression of the 1930s. It was acquired by the chairman of West African Newspapers Limited, R. B. Paul who was based in Liverpool. He owned the newspaper till 1947, when it was 
also taken over by the chairman of the London Daily Mirror Group, Cecil Harmsworth King who turned the newspaper around. The great feats of Cecil king in journalism, press technology ad entrepreneurship shot the Daily Times into prosperity and fame. With Cecil king takeover, Daily Times shed the toga of conservativeness. It began to play active role in Nigeria politics (Duyile, 1989)

Daily Times was the first newspaper to set up a training school under the directorship of Alhaji Babatunde Jose (Jose, 1987). The power and fame of Daily Times magnetized the federal military government of Nigeria under General Murtala Ramat Muhammed to take over the newspaper for the third time in 1975 . The paper was always asking the government to submit its governors for probe and to hand over government to civilian.

\section{Zik and the West African Pilot}

Dr. Nnamdi Azikiwe started the West African Pilot with the first edition on 22 November, 1937. It was the beginning of another fire brand journalism in Nigeria. Unlike Herbert Macaulay who was a civil engineer, Nnamdi Azikiwe was a trained journalist and graduate of political science and anthropology, His journalism practice began in America where he worked as a reporter and in Ghana as an editor of the African Morning Post from 1934 to 1937. He came to Nigeria during the struggle for independence in 1937 and immediately launched the West African Pilot the same year.

Zik brought innovation into journalism practice in Nigeria and dictated the pace for its older colleagues in pictorial coverage of news. For the first time, the newspaper digressed from its contemporaries by giving attention to the coverage of issues concerning people at the lower cadre. As a result, it attracted mass appeal. With a stone art courage and boldness, he launched attack on colonial administration. The Pilot was progressive and acceptable by the people and consequently, Zik set up a high standard for the paper. He set up a chain of newspapers which was known as Zik Group of papers. Some of the newspapers were Nigerian Spokesman based in Onitsha, Nigerian Defender based in Warri, the Comet based in Kano. He later established the Northern Advocate in Jos. Zik chain of newspapers were conspicuous, outspoken on issues of nationalism, African unity and other nationalistic sentiment. As a result, echoes of Zik's brand of journalism was heard beyond Nigeria and indeed Africa (Duyile, 1989, Daramola, 2013).

The West African Pilot challenged the dominance of the Daily Times of Nigeria and in fact at a time became a leading newspaper in Nigeria inspite of the retinue of expartriate staff in Daily Times and modern printing machinery. West African Pilot's doggedness and nationalistic fervor was attested to by Chief Obafemi Awolowo, one of the political rivals of Dr. Nnamdi Azikiwe in the following words: "The Pilot, whatever, its literary defects, was a fire eating paper of the highest order, ranking in this regard with the Nigerian Telegraph edited by Ernest Ikoli and the Lagos News, but much better produced. It is to the credit of Dr. Nnamdi Azikiwe that the standard laid by his predecessor particularly, Robert Campbell that the Nigerian press shall never consult anyone as to what we shall say or what shall for bear to say was maintained and raised to the bar by the West Africa
Pilot. That tradition of freedom continues to date.

\section{Nigerian Tribune}

The Nigerian Tribune was published by late Chief Obafemi Awolowo on November 16, 1949 through the African Press Ltd in Ibadan. It was a political newspaper which was used to promote his ideology and a training ground for future leaders of Nigerian press.

Awolowo was a great vocalist in nationalist politics. His editorial was dynamic and fearless. The nationalist posture gave him honour and respect. The newspaper is very unique amongst all the newspapers before it because it has been published regularly since its inception (except briefly in April, 1986 during the Tribune journalists NUJ protracted crisis). In 1962 when the Action Group split into two-one led by Chief Obafemi Awolowo and the other by Chief Samuel Ladoke Akintola who was Awolowo's deputy - the Tribune as usual was totally involved and was to Awolowo's advantage. The crisis led to the establishment of Daily Sketch in 1964 as a rival to Chief Awolowo's Tribune and Action Group. Then Chief Akintola had founded NNDP which was in league with the Northern Peoples Congress at the centre. It was this attitude coupled with its ruggedness and ability to survive any crisis that distinguished it from its contemporaries, the West African Pilot.

Nigerian Tribune was the first paper to practice what is called guerrilla journalism publishing in an undesignated places to the dismay of security agents who had hitherto sealed off the official printing press at Ibadan. Duyile (1987:182) attests to this when he said, "the Tribune will emerge on the newsstands and the streets the following day with unbelievable precision, among the newspapers published in Nigeria". The Tribune had been a courageous newspaper, always publishing and be damned no matter whose ox is gored.

The Nigerian Tribune could be likened to the Weekly Record of the Jacksons in its ruggedness, doggedness and anti-colonialist stance which laid so much emphasis on representative government. Chief Obafemi Awolowo had made clear the newspaper stand on 14 June, 1958 in his address to Nigerian Union of Journalists, Ibadan as he said, "to disseminate news accurately and to criticize pungently demand that the press should possess sufficient courage and impartiality to play a role which may please some and displease others". There are those who would like certain news suppressed which in the interest of the pubic should be given the widest publicity. They are acts of the people or of the government which certain newspapers would not criticize lest they should cause offence and thereby lose circulation. Democracy, demand, however, that the truth should be told always and that charlatans and saints should be called by their proper names" (Duyile, 1987:183).

Awo's paper gave him leverage and by publishing his manifestoes, he was known as a socialist and a utilitarian who believed in the greatest good of majority. And with this he rose to become the premier of the Western Region. $\mathrm{He}$ introduced free education as part of the socialist policies in 1955. He gave scholarship to students to study abroad. Education was the bedrock of his policies. His type of education was qualitative, comprehensive and devoid of class. The children of the poor had access to good and functional education. As a result, Awo was seen 
as a God-sent by many who wouldn't have had the opportunity. This action endeared many to him and this helped him politically.

Awo's legacy is also conspicuous in trade and commerce. For example, he brought in investors into Western Region such as Coca Cola plc, John Holt, he established Oodua Investment which has tentacles within and outside the country. The Oodua conglomerate are involved in textile, oil and gas, banking and finance and transportation. Awos led administration built a 12 -storey cocoa house in the capital of Western region, Ibadan from the money derived from cocoa, his government constructed the first stadium in Ibadan recently named after him, Television station in Ibadan and the first regional radio station in Nigeria. The establishment of Tribune contributed to Awolowo's gain in politics and he used the paper to whip his opponents to line.

In mid 50s, Chief Awolowo became the Premier of Western Region and in 1960, became leader of the opposition in the parliament in Lagos. Chief Awolowo served as the vice-chairman of the military council under General Yakubu Gowon military administration after his release from prison for treasonable charges. He was also minister of finance and at the same time security adviser to Gowon administration who contributed to the end of the protracted civil war which lasted three years (1967 1970).

Chief Awolowo was a thinker, scholar, author and reputed as a man who saw tomorrow. He missed being Nigeria president thrice, first in 1959, second 1979 and lastly in 1983. He lost not due to his lack of support from Nigerians but to the political structure which still prevails till date where the best candidate does not necessarily win election in Nigeria. Chief Obafemi Awolowo was conferred with the highest honour of the land, Grand Commander of the Federal Republic (GCFR) in 1982 by President Shehu Shagari. As a result of Awo's sagacity and charismatic leadership, Colonel Odumegwu Ojukwu, leader of the defunct Biafra described Obafemi Awolowo who was his arch enemy as "the best president Nigeria never had".

\section{The North and Gaskiya Twafi Kwabo}

Gaskiya Tafi Kwabo, a vernacular newspaper was established in the north in 1939 by the colonial master to spread information about the Second World War to the people of the north (Duyile, 1989). The north as at that time had a one party political culture and unlike other regions in Nigeria which had different political parties and views, the north spoke in one voice. It was not the first Hausa language newspaper but it had wider spread. The paper lend its voice to Nigeria nationalism of the period. It was an effective interpreter to the north of all that was going on in the south and elsewhere. It enjoyed a stable source of finance and the ruling party almost converted it to its own megaphone.

\section{Post Independence Newspaper}

Nigerian newspapers continued in the tradition of freedom already laid down by their predecessors e.g. the Weekly Record of Jackson, West African Pilot of Nnamdi Azikiwe, Nigerian Times of James Bright Davies etc after independence to date. There are many newspapers that came on board, some still existing, many gone into extinction. During the colonial era, the press had a common enemy, common goal, and common agenda which was independence and this acted as a catalyst for cooperation except but a few e.g. the Pioneer of Kitoyi Ajasa which had sympathy for the colonialists due to financial and moral gains. With the departure of the colonialists there was no longer the common enemy, there was no longer the catalyst, the press then turned against each other. Many of the newspapers divided along regional, political and religious lines. Each of them agitating for regional interests and no longer national interest. The new Africans that became either presidents or prime ministers were busy doing nothing after independence.

The press that was acting as the watchdog of the British colonial government was at each other's throat and sometimes pandered to the interest of their proprietors who are usually politicians. They forgot about ethics of journalism and the common goal which was the development of the new independent states. To make things worse, government itself started establishing newspaper, radio and television stations with good financial backings e.g. The Sketch of Samuel Ladoke Akintola in the Western Region, Morning Post of Prime Minister Abubakar Tafawa Balewa, New Nigerian of Northern regional government, Radio and television stations by Western, Eastern and northern regional governments and Daily Times which was acquired in 1975 by Murtala/Obasanjo military administration.. They drove many of the old privately-owned newspapers out of circulation.

\section{Nigerian Press and Democracy}

The role of Nigerian press to the entrenchment of democracy is as old as Nigeria itself. It must be mentioned that the Press actually started agitation for self determination, representative government and ultimately, democracy. This was dated back to 1881 when the Lagos Times and Gold Coast Colony Advertiser owned by Richard Beale Blaize fired the first Salvo in his edition. The newspaper was amazed that the legislative and executive council of the period were wholly manned by the British colonialist. Seeing the imbalance, Richard Blaize cried out at the exclusion of Nigerians in the administration and decision making bodies of their fathersland.

This agitation continued with subsequent newspapers such as the Weekly Record of John Payne Jackson and his son, Horatio Jackson, the Standard of A. Williams, Lagos Daily News of Herbert Macaulay, West African Pilot of Dr. Nnamdi Azikiwe, Nigerian Times of James Bright Davies, Nigerian Tribune of Awolowo, Daily Service of Samuel Ladoke Akintola and the present generation of Nigerian newspapers including of course the dead and surviving newspapers and magazines such as the National Concord of MKO Abiola, The Punch of Olu Aboderin, Newswatch Magazine of Dele Giwa and others, Tell Magazine of Nosa Igiebor and others, THE NEWS magazine of of Bayo Onanuga, The Guardian of Alex Ibru and ae host of others.

Democracy is a government of the people, for the people and by the people. The mass media are the foundation for democracy anywhere. All through our history journalists were in the forefront for the entrenchment of party politics. 
The first officially recognized political party in Nigeria was that of Herbert Macaulay, a newspaper man. The party was known as Nigeria National Democratic Party (NNDP), he was also the first president of the National Council of Nigeria and the Cameroon (NCNC) another political party formed in 1944 by Nnamdi Azikiwe and others (Omu, 1978). Herbert Macaulay was the publisher of Lagos Daily News, he was a committed politician and the newspaper became a major weapon in the nationalist struggle. He was a believer in African freedom and human rights. During his time, the Lagos Daily News got involved in many local and national issues, like the water rate agitation of 1908, the campaigns for election into legislative council, etc. This successful newspaper campaign and Weekly Record of Horatio Jackson led to the victory of his NNDP which won the three seats reserved for Africans in the council in 1923, 1928 and 1933 (Duyile, 1987:100).

Many others toed this line. The likes of J. S. Leigh publisher of the "Lagos Echo" who not only planted the seed of patriotism but also participated in party politics of that period. He toed the seed of self rule.

The involvement of journalists in the formation of political parties provided one explanation for the heated participation of newspapers in elections. Newspapers shifted their focus from that of political group supporters to organs of political parties. The mass media in Nigeria had all along produced politicians who, one way or the other, influenced the politics of the country at any given time. It must also be observed that men like Chief M. K. O Abiola used his Concord Group of newspapers to campaign for the victory of the Social Democratic Party (SDP) in the1960. After the independence particularly in military era the Nigerians press challenged all the military regimes that ruled this country, and they paid dearly for it. This led to such actions as the promulgation of draconian laws, arrest and detention of journalists, imprisonment of editors, proscription of media house and seizure of offending publications by the military (Omu, 1978, Duyile, 1989, Daramola, 245).

This is a big challenge to historian, mass communication and, political science scholars and the rest. This may form a plank of many studies for future researchers.

\section{The Media and Education in Nigeria}

The media in Nigeria and indeed Africa has played, is still playing a very important role in the entrenchment and development of education in all its ramification. From around 1859 till date, the Nigerian media through its publications has always been critical of government policies in education and has always been a vocal advocate for the improvement of a bad system or an ineffective administrator. The fact remains that a journalist must first be educated and if one trace the history of the mass media in Nigeria one would conclude that the mass media was the foundation of good and qualitative education in Nigeria.

And if we analyze the media and education in Nigeria we would observe that most of the fathers of journalism in Nigeria had their foundation firstly in education and politics and most of them ended up in the rulership or leadership in Nigeria. As individuals they contributed in no small measure to the improvement of education and some of them formulated the educational policies of Nigeria.

If we take a nostalgic look at education, we would see that the missionaries introduced education to Nigeria and Africa in general. With time they (missionaries) realized that schools were important to bringing converts into their churches. This is exactly what informed Rev. Henry Townsend paper as he himself said, at the outset of the newspaper, "My object is to get the people to read, that is to beget the habit of seeking information by reading" (Coker, 1968:1). Along this desire was that each time the missionaries set up a shed for church service on Sunday, the shed was used as school during the week where they teach the converts. The education system was patterned along British type of education. As noted by Osoba and Fajana (1980:570) "this foreign variety of education has co-existed ever since with different forms of indigenous education". The scholars traced the history of education to the arrival of the missionaries in the 1840s with the establishment of schools to catch the young ones so as to attract converts or their children.

The type of education was aimed at producing "school masters" who were to graduate to catchists, deacons and then priests. Subsequently, few secondary schools were established, they included the CMS Grammar School, Lagos (1859), the Roman Catholic Teachers' College (later St. Gregory's College), Lagos and Methodist Boys High School (1878) which were established under the auspices of the various missions. As part of the development, the colonial government established more secondary schools, Teachers' Colleges and a University College at Ibadan in 1948. Few children of the rich were able to travel to England to further their education. This produced the earliest lawyers, engineers, medical doctors, surveyors, etc.

However, these products of mission schools soon realized after being educated that they were being denied equality in housing, civil service and social life by the British. This discrimination led to the spirit of nationalism in the educated Nigerians. Men like John Payne Jackson, James Bright Davies, Tejumade Osholake Johnson, to mention but a only a few were at the head of nationalism. In cooperation with other educated Nigerians such as Dr. Nnamdi Azikiwe, Chief Obafemi Awolowo the struggle continued. Lagos remained the centre of national resistance to British rule. This, according to Olusanya (1980:546) was among other things due to presence of such facilities like the press which were available for use. Dr Nnamdi Azikiwe, a leading nationalist of the period was consistent and persistent in drumming it to the hearings of other nationalists that Nigeria might have been a geographical expression but had become a historical reality. Nigerians of that era saw themselves not as a disparate group each seeking its own selfish interest, but as a single individual struggling for social justice and freedom. Whether resident in Lagos or outside of it, the national leaders showed a great concern for the interest of Nigerians in every part of the country.

Olusanya (1980) cited John Payne Jackson who through his newspaper the Lagos Weekly Record often vehemently denounced the British for waging wars against indigenous states, condemned them roundly for attacking Itsekiri land in 1894 and for deposing Nana Olomu, and protested against the British occupation of Benin in 1897. George 
Alfred Williams' Standard described the bombardment of Oyo in 1895 as " a diabolical tragedy" and spoke of the British marching through the world armed to the teeth and like a roaring lion going about and seeking whom he might devour, while Christopher Josephus Johnson's Nigerian Chronicle hotly condemned the military expeditions which were common in the period of so-called pacification.

The missionaries then went on to reducing spoken languages of Africa into writing. Before 1878 very few language in sub Saharan Africa had an alphabet and means of writing. The early missionaries made an alphabet with letter to meet the need of each local language. And as a result many tribes in Africa were able to keep records for the first time in their history (Babalola, 1981). The first newspaper in Nigeria was the "Iwe Irohin fun Awon Ara Egba ati Yoruba" published then by the Rev. Townsend. Thus, Rev. Townsend pioneered the development of newspaper press in Nigeria. The establishment kick started the mass rush to be educated.

\section{Media and Military}

Post-independence Nigeria witnessed the incursion of the military into Nigerian politics. The military created unfriendly and harsh environment for the press. In its usual characteristic manner the military were always banning political parties and placing the constitution on suspension, the Press therefore served as peoples' parliament under military administration. However, the positive thing the military did for the press is to help them make a detour to realize a common goal again which is to collectively fight on behalf of the people. They published news about the military and fed the military back on the views of the people without fear or favour. This often led to proscription of newspapers, detention and imprisonment of journalists, or even death. The death of Mr. Dele Giwa one of the founding fathers of the defunct Newswatch magazine in 1986 whose killers are unknown till date is a good example. Another good example is the ill treatment meted on Mr. Miniere Amakiri, a River State correspondent with the Observer, a Midwest state newspaper in 1974. The offence of Amakiri was that on birthday of the then Rivers state military governor, Edet Spiff, the Observer published the impending teachers' strike in Rivers state. As a result, Mr. Amakiri was beaten blue and black on the order of the military governor. Thereafter, Amakiri head was shaved with rustic blade. The court, however, ruled in favour of Amakiri and NUJ, in the ensuing litigation.

The Nigerian military took over the political scene, when on January 15, 1966 Major General J. T. U Aguiyi-Ironsi assumed the headship of the country when major Chukwuma Kaduna Nzeogwu coup was foiled. This turn in event marked a dramatic change in journalism in Nigeria. The military proclaimed a state of emergency and this had direct effect on the Nigerian press. The military suspended the constitution which at that time guaranteed press freedom. Although the press under the civilian rule used to regularly have disagreement. Under the military it can be described as a child's play. They directly impinged upon the rights of the press.

The Nigerian press could no longer report things the way they had been doing all along under civilian rule. The military promulgated many anti-press laws. Following the death of Major General Aguyi Ironsi on July 15, 1966 , through a counter coup, General Yakubu Gowon took over and at the outset of the civil war his administration promulgated the Newspaper (Prohibition) Decree no 17 of 1967, the decree was invoked against the Biafra Sun newspaper. That was the beginning of a calculated attempt of the military to gag the press. The rights of individual journalist and media houses were violated, especially through Decrees. The decree was used more against the press than any other section of the society.

General Yakubu Gowon's era was just the beginning of the systematic repression and suppression of press system in Nigeria. The military intervention into politics had proved disastrous for Nigeria and Nigerians. Nigerian press was not silent in the nine years rule of General Yakubu Gowon. In his assessment of the role of the press, Arnold (1977) described the Nigerian press as the most outspoken, volatile, within and in black Africa given the critical and undaunting editorials about the military. He went on, "Its criticisms of government and establishment are far raging and pointed, its pursuit of the pompous and incompetent can be very funny as well as relentless, its coverage can be exceptionally wide and also, sometimes parochially narrow..." Nigerian press was persistent in calling on Gowon regime to return to civil rule and probe allegation of corruption. One article in the July 10, 1975 edition of Nigerian Tribune said:

General Gowon may not be a very old soldier but the time has come for him to fade away. We are now in the position to ask ourselves why are we in the total darkness of today? The reason is simple. We never had a course to steer.

Speaking further on the frustration of Nigerians under military government, the article went on:

The question on the lips of everybody today is, how do we get out of this rot? How do we get the Nigerian society re-charged and so restart a new life of buoyancy and creativity? ...the army, we should be told is made up of individual fellow Nigerians from all over the place. We, civilians would be wrong to think these soldiers have come from a different planet with special powers to resolve all our difficulties for us. Their weakness we know. Their strength for what it is worth - is visible everywhere.

Incidentally, that year General Gowon's regime was overthrown by Brigadier Murtala Muhammed on Tuesday 29 July, 1975. A week later in a far from unkind appraisal of Gowon a writer in the Sunday Times of 10 August, 1975 wrote: 
For my own part, I am sorry to see General Gowon miss a golden opportunity for immortalizing his name. He ran a beautiful race but pulled a muscle as he was approaching the tape. $\mathrm{He}$ prepared a delicious dish but overturned the pot at the service table. He wrote an excellent speech but lost his voice at the time of delivery.

In a nutshell, the Nigerian press has always been the peoples parliament as earlier posited by Alhaji Lateef Jakande, the Chairman of the Newspaper proprietors Association:

The Nigerian press is not
against and will never work
at variance with the
objectives of the federal
military government.
Rather, the press which at
the moment is the parliament
of the people, should not
only report the activities of
the government but also
supply the feedbacks from
the people those who attack
the press do so out of
misunderstanding.

Writing about corruption, Nigerian Tribune of 10 July, 1975 sarcastically wrote: "Of course nobody can accuse any member of the government of corruption. Nobody that is, who wishes to being thrown to jail".

Six weeks later, precisely on September 1, 1975 the new government (Murtala government) took control of the country's largest independent newspaper, the Daily Times and Sunday Times, as well as the New Nigerian. Today, the Daily Times is dead and New Nigerian is a shadow of itself.

On July 29, 1975 General Murtala Ramat Muhammed who toppled the government of Yakubu Gowon in a bloodless coup was assassinated on February $13^{\text {th }}, 1976$ after only seven months in office. His second-in-command General Olusegun Obasanjo replaced him as Head of State. They were aware of the power and influence of the newspaper an so in other to reduce the influence of the newspaper, the Daily Times thus invariably became the mouth piece of the government. Any reporter who did not toe the line was either sacked or detained. The regime acquired the paper through a decree titled "The Daily Times of Nigeria Limited" (Transfer of certain shares Decree 1979). Obasanjo also promulgated the Nigeria Press council decree No. 13 of 1978, which was roundly condemned and rejected by the press. Here are some examples of journalists who suffered in one way or the other under the Obasanjo/Murtala regime. Chris Okolie the publisher of the New Breed magazine was detained in February 1977. Bisi Oloyede the Acting Lagos editor of the Daily Sketch was also detained in March 14, 1977. Luke Iyima a reporter with the Nigeria Standard was detained and tortured (Mabadeje, 37).
Concerning the new regime of Brigadier Murtala Muhammed, the Sunday Times of 3 August 1975 warned:

Perhaps it is rather
premature to start running
commentaries and issuing
elegies on the new-
overthrown regime. For one
thing, nobody can say with
any certainty what is up the
sleeves of the new rulers.

After much agitation by the press, General Olusegun Obasanjo eventually handed power back to civilians on October 1, 1979. That gave birth to the second republic with Alhaji Shehu Shagari as president. With democracy now in place, democracy did not change the plight of the ordinary Nigerian. Things became so bad there was a breakdown in every sector of the country, violence became the order of the day. The press was called into action again they were very critical of the level of corruption in the then administration of Alhaji Shehu Shagari. Opposition papers such as Nigerian Tribune, Punch, Sketch et al were very vocal. Contracts were inflated, indiscipline was unlimited. It was at this critical period that austerity measure was introduced in political landscape of Nigeria. It got to a stage that the masses and the press were virtually calling or praying for a return of the military to "salvage" the situation (Mabadeje:39).

And indeed the military struck on December 31, 1983 and in turn took over the political turf of Nigeria. Major General Muhammed Buhari took over as the Head of state. The Nigerian press would not forget in a hurry the contribution of that regime and others that took control of power after him, General Babangida and General Sani Abacha. The press which used to be professional, courageous, mighty and efficient was put under serious test under these regimes. The era could be termed as the dark days for journalistic practice in Nigeria. All this three regimes were ruthless, high handed, intolerant and dictatorial. The Nigerian press regretted the initial support for the regime. And this marked a turning point in the lives of practicing journalists in Nigeria, who suffered greatly from length detention, imprisonment, torture and even death.

On assumption of office of the Buhari administration on December 31, 1988 most politicians of the second republic were arrested and sentenced to various jail term. The regime's said it would fight bribery and corruption and other social vices and indeed introduced war against indiscipline (W.A.I) policy. The Buhari/Idiagbon virtually removed everything called freedom from the Nigerian press. The regime suspended chapters iv of the 1979 constitution and also precluded the courts from enquiring into any act done or intended to be done under it. This was the height of impunity. Dr. Tai Solarin was arrested and detained under Decree No 2 for 18 months for advocating return to civil rule (Mabadeje:42). Two journalists, Tunde Thompson and Nduka Irabor fell victim of Decree 4 promulgated to muzzle press, they were subsequently jailed one year each and fined, their media house (The Guardian) was fined, fifty thousand naira (N50,000). His regime dealt with politicians, many were found guilty of corruption and gross indiscipline and were punished with various jail terms. He declared that his regime would rid 
the country of corruption..

On August 27, 1985 the repressive regime of Buhari was toppled by General Ibrahim Babangida Babangida initially released all detained journalists that were arrested under Decree 4, 1984. But he later began to engage acts that were inimical to press freedom. The death of a journalist Dele Giwa via a letter bomb was recorded under the regime of Ibrahim Babangida. The killing of Dele Giwa the founding editor of the Newswatch Magazine marked a turning point in the practice of journalism in Nigeria in general. The late Dele Giwa was the pioneer of investigative journalism in Nigeria. In 1993, the press accused General Babangida of trying to succeed himself as a civilian president.

The Nigerian press clamour for democracy continued under General Ibrahim Babangida administration and became critical of the government when the administration kept on postponing its transition programme when on June 26, 1993 the presidential election won by the Social Democratic Party (SDP) candidate, M.K.O Abiola was annulled. The press and other Nigerians collectively denounced the cancellation of the June 12 presidential election as a rape of democracy.

The Nigerian press became the pivot and arrowhead of the struggle to validate the result of the election. Through articles, news reports, features, commentaries and editorials, the press condemned the decisions and actions of the military government (Mabadeje: 46). The era led to the harassment, torture, arrest and detention of journalists. The onslaught on the media by the Babangida regime was first of its kind to have ever happened to the press in Nigeria.

On August 27, 1993 General Babangida "stepped aside" due to pressures from the media, civil society and the general public with some media houses running underground. They did not make life easy for him. He left behind an interim National Government led by Ernest Shonekan but with widespread protests and law suits challenging the constitutionality of the ING, Ernest Shonekan's government was swept out of office in a palace coup by General Sani Abacha on November 17, 1993. On Assumption of office Abacha re-opened the media houses that had been shut down by the Babandiga's regime to gain public acceptance and be in the good books of the mass media.

General Abacha later became an enemy of the press when he started repression and suppression of the press that were rightfully agitating for a return to democracy. When it became a well known fact that General Abacha wanted to succeed himself in office as a civilian president and the press was the arrowhead of the people's opposition to realizing the self succession bid. General Abacha was named as the number one enemy of the press in the world on May 3, 1998 by the CPJ on the World Press freedom day (source). After this declaration the regime pounced on the media. Journalists were arrested without trial and those who were put on trial received lengthy prison terms. The regime of Abacha was the worst era for the Nigerian press. Journalists were arrested, detained and persecuted.

\section{The Press in Fourth Republic}

A new political dispensation was ushered in on May 29,
1999 when General Abdulsalami Abubakar administration handed over government after a peaceful election to a democratic government led by Chief Olusegun Obasanjo. This is after much struggle and agitation by the press and NADECO for a return to civil rule. With democracy, the press began to play its watchdog role and in obedience to the constitution holding government accountable to the people.

In performance of this duty, the press exposed the first speaker of the House of Representatives, Alhaji Salisu Buhari. The speaker was discovered not to possess the academic eredentials he claimed. This led to the resignation of the speaker from office.

In April through May 2006, the Nigerian press vehemently opposed attempt by the then president, Chief Olusegun Obasanjo to elongate his tenure through a constitutional change of tenure of two terms to third term for a president. The press opposed the debate in House of senate and the House of Representatives, calling such action as undermocratic, criminal and dictatorial. The opposition of the press put the legislators in shame and made them drop the idea.

The press has also been in the forefront of fighting corruption, lawlessness nad insincerity of politicians at various levels. For instance, the press was partner in progress of the Economc and Financial Crimes Commision (EFCC) in the hey days of Nuhu Ribadu as chairman of the commission. On his part the press exposed a key member of the ruling party, Peoples Democratic Party, Chief Olabode George who was jailed two years in Lagos for corrupt practice while on the Board of Nigeria Ports Authority as chairman. The Nigerian press did not hide its feeling when she kept on eulogising president Umaru Yar'Adua as his administration obeyed the rule of law. Same goes for the press which subjected President Goodluck Jonathan's administration to public scrutiny at least for promoting corruption and laxity among politician.

\section{CONCLUSION}

The mass media was the ultimate defender of human rights under the law and the quest for equality. It is a known fact that successive governments had continued to view and also attempt to use the media for propaganda to support government policies. Knowing this the mass media then started to act as a "watchdog" of government and its officials by carefully dissecting government policies in their editorial analysis.

The media has assisted in building and maintaining an environment conducive for democracy. The media managed to maintain its independence even during the repressive military era. The media also played the role of providing a link between the rulers and the ruled. It was always acting as the parliament of the people when the need be.

We can also recall that the pioneers of the Nigerian press held their own in establishment of a virile press at a time when, in colonial territory, freedom of expression was not respected as a right but as a privilege. Recalling a quotation from the colonial Governor of Lagos, Sir. William McGregor, who referred to our newspaper correspondents as "Mission educated young men who live in villages interfering with the native councils, and acting 
as correspondents for the mendacious native press". Today, the ethics of journalism has not changed much, because, the pioneers had laid down a strong foundation for it to build upon. The media has thus become a friend of the downtrodden men and women of society and the champion of the oppressed. It was once said that the struggle against oppression and poverty has been a remarkable feature of human history but great journalists have used their brains and writing skills to salvage mankind from misery. The newspaper is a nation's single source of daily dialogue about politics, culture and social issues.

However, the Nigerian press appears to be falling apart in terms of integrity. The performance of the mass media in the 2015 general elections leaves much to be desired. The despicable role of both the private and government-owned media organizations especially in form of advertisement and news reportage called for question. One of the most widely read newspapers in Nigeria on January 19, 2015 published a death-wish advertisement against one of the presidential candidates who eventually emerged the winner of the elections held on March 28, 2015. Another respect newspaper was fond of negative advertisements against a particular political party's candidate during the electoral campaign. The most worrisome was a private television station which devoted its time to negative advertisement and hate message against the opposition party.

This is the least expected of Nigerian press which had hitherto been the pacesetter and agenda setter of politics in Nigeria. In 2015 general elections, the press threw caution to the wind and became partisan, supporting the ruling party to a fault.

\section{REFERENCES}

[1] Abiola vs. Tofa 1993. Newswatch April 12.
[2] Akin-Aina, W. 1994. Abiola in the Dock, Lagos: Newswatch, July 18.

[3] Arnold, G. 1977. Modern Nigeria, London: Longman Group Ltd.

[4] Coker, I. H. E 1968. Landmarks of the Nigerian Press, Lagos: University of Lagos Press.

[5] Daramola, I. 2013. History and Development of Mass Media in Nigeria, Lagos: Rothan Press Ltd.

[6] Duyile, D. 1987. Makers of Nigerian Press, Lagos: Gong Communications (Nigeria) Ltd.

[7] Edremoda, K. ad Aturu, B (Ed) 2009. Party Building in Nigeria, Abuja: Democratic Alternative.

[8] Elte, M. 1994. Under the book, Newswatch, September 19

[9] IBB steps down, Newswatch, August 30, 1993.

[10] Mabadeje, I. 2004. The Nigerian Press under the Military, Uyo: Robertminder International Ltd.

[11] Olurode, L and Anifowose, R 2004. Issues in Nigeria's 1999 General Elections, Ikeja: John West Publications Ltd.

[12] Olusanya, G. O. 1980. "Nationalist Movements" in Ikime, O. (ed) Groundwork of Nigerian History. Pp $545-569$

[13] Omu, F. I. A 1978. Press and Politics in Nigeria, 1880 - 1937, London: Longman Group Ltd.

[14] Osode, S. O. and Fajana, A. 1980. Educational and Social Developments" in Ikime, O. (ed) Groundwork of Nigerian History, Ibadan: Heinemann Educational Books. 